\title{
Tatar Mitolojisinde İyeler The Familier Spirits in Tatar Mythology
}

\author{
Rasilya KARIMOVA ${ }^{1}$ \\ Kocaeli Üniversitesi
}

\begin{abstract}
Özet
Kazan Tatarlarının hayatında ve halk edebiyatında Tatar mitolojisinin özel ve önemli bir yeri vardır. Tatar mitolojisi ile ilgili unsurlar değişik başılılar altında incelenebilecek çok renkli, zengin ve çeşitli bir yapıya sahiptir. Bu çalışmada, zengin Tatar mitolojisi ve Tatar halk inanışları içinde önemli bir yer tutan iyeler (koruyucu ruhlar) konusu ele alınmaktadır.

Günümüz Kazan Tatarlarının günlük hayatlarında iyeler olarak Su Dedesi, Su İyesi, Su Anası (Su Kızı), Su Atası; Çeşme İyesi, Dağ İyesi, Ev İyesi, Ahır İyesi, Munça (Hamam/Sauna) İyesi, Orman İyesi, Cami İyesi ve benzeri gibi muhtelif iyeler vardır. Tarihî gelişim ve modernleşme her ne kadar bu iyelere olan inancı biraz zayıflatmış olsa bile günümüzde de Tatar halkı arasında bunların varlığına inanılmaya devam edilmektedir. Başta Tatarların millî şairi Abdullah Tukay olmak üzere, diğer şair, yazar ve sanatçların ele alıp sanat yolu ile de işledikleri iyeler bu şekilde varlıklarını daha güçlü bir şekilde devam ettirmekte ve yeni nesillere aktarımaktadır.

Kutsal ruhlar olan iyeler doğa ile yakın ilişki içindedir. İyeler, insan-doğa ilişkilerininin düzenlenerek karşılıklı saygı içinde devam ettirilmesine destek olma, olumlu davranışları destekleyip olumsuz davranışları ise değişik şekillerde cezalandırma gibi türlü özelliklere sahiptir.

Bu çalışmada Kazan Tatarlarının halk inanışları ile ilgili belli başı iyeler ele alınmış, bu iyelerle ilgili bilgilere yer verilmiştir.

Anahtar Kelimeler: Kazan Tatarları, mitoloji, efsane, halk inançları, iyeler (koruyucu ruhlar)

Abstract

Tatar's mythology is important and special for Kazan Tatars' life and folk literature. Tatar mythology has colorful, rich and various patterns. In this study, it is dealt with the important subjects which is significant for Tatars' mythology and beliefs in Tatars'.

In daily life of modern Kazan Tatars there are some familiar spirits such as $\mathrm{Su}$ Dedesi, Su İyesi, Su Anası (Su KIzı), Su Atasl; Çeşme İyesi, Dağ İyesi, Ev İyesi, Ahır İyesi, Munça (Hamam/Sauna) İyesi, Orman İyesi, Cami İyesi etc. Although historical developments and modernity weakened the belief of the proprietors, Tatars are going on on believing them. As the principle poet of Tatars Abdullah Tukay, other poet, author and artists should take it into consideration and handle these proprietors, by this way they will survive more strongly and be turned over to new generations.
\end{abstract}

\footnotetext{
${ }^{1}$ Kocaeli Üniversitesi Sosyal Bilimler Enstitüsü Türk Dili ve Edebiyatı Ana Bilim Dalı Yüksek Lisans Programı Öğrencisi. el-mek: rasilya@bk.ru
} 
Proprietors, which are holy spirits are in a good relation with nature. Proprietors have features like organising people-nature relationship and sustain it in a respectful way, supporting good habits and punishing bad habits.

In this study, some proprietors which are related to Kazan Tatars public beliefs are taken into consideration and some informations about there proprietors are used. spirits)

Key Words: Kazan Tatars, mythology, legend, folk beliefs, proprietors (familiar

\section{Tatarlar}

Oldukça eski bir tarihî geçmişe sahip olan Tatar halkının ataları VI. asrın başında İdil-Ural Bölgesine göç eden Bulgar Türkleridir. Şimdiki İdil-Ural Tatarları Suvar, Sibir, kısmen Hunlar ve İdil Bulgarları ile XII. asırda Türkistan'dan gelerek bu bölgeye yerleşen Kıpçak Türklerinin torunlarıdır. Bulgar Türkleri VI. asırda İdil-Ural bölgesine yerleşmeye başlamış ve VII. asırda bu bölge tümüyle bir Türk yurdu hâline gelmiştir (Fäxrétdinov, 1996:27-56).

Tarihte Kazan Tatarları ile ilgili siyasî yapıları İdil-Bulgar Devleti, Altın Ordu Devleti, Kazan Hanlığı ve hem Sovyet Sosyalist Cumhuriyetler Birliği döneminde hem de SSCB'nin yıkılması sonrası kurulan Rusya Federasyonu içinde yer alan Tataristan Özerk Cumhuriyeti şeklinde sıralamak mümkündür.

\section{Mitoloji}

Mitoloji, mit bilimi anlamına gelir (Seyidoğlu, 1995:9). Fatix Urmançé (2002:35), mitolojiyi, değiş̧ik halkların mitlerini inceleyen bir bilim dalı veya belli bir milletin mitlerinin toplamı şeklinde tanımlar. Tatar Télénén Anlatmalı Süzlégénde (Abdullin, 1979:397) mitoloji, mitlerin toplu şekli, mitler sistemi; mitleri inceleyen bilim olarak tanımlanır. Birbirine zıt olan rasyonel ve irrasyonel başlangıçların ortak noktası olan mitoloji, diyalektik yönden içeriği ve yapısı ile farklı bir mahiyete sahiptir (Bakirov, 2014:45).

Mitler, ilkel insanın dünyanın ne zaman, niçin ve nasıl var olduğu gibi önemli sorulara cevap araması sonucu ortaya çıkmıştır. İlkel insanın dünyayı anlamaya çalışması onun tecrübelerine ve gözlemlerine dayanır. Bilim, felsefe, siyaset ve sanatın temelini de mitoloji oluşturmaktadır (Däwlätşin, 2009:7).

Dinler ruhsal dünyaya açılan kapılardır. Ancak Dünya'ya insan formunda doğan varlığın geldiği dünya ile irtibatını unutmamasını sağlayan sadece dinler değildir. Dinlerle birlikte Felsefe ve Mitoloji de üçü bütünü (Din, Felsefe, Mitoloji) oluşturan diğer unsurlardır (Candan, 2015:273).

İnsan düşüncesinin gelişmesini çeşitli gelişme evrelerine ayıran Max Müller, insan düşüncesi ile dilinin tematik dönem, diyalektik dönem, mitolojik dönem ve popüler dönem olmak üzere dört evreden geçtiğini belirtir. Buna göre mitler, insanlık tarihinin gelişme çizgisinde daha geç dönemlerde oluşmuşlardır (Çobanoğlu, 2005:102). Ancak, gelişim aşaması yönü ile ortaya çıkışları geç dönemlere denk gelse de mitolojinin ve dolayısı ile mitlerin insanoğlunun hayatı üzerindeki etkisi çok güçlü olmuştur. 


\section{Halk İnançları}

Halk inanışlarının kaynağı hiç şüphesiz halkın tarihî geçmişi, kültürü, yaşadığı coğrafya/çevre ile doğrudan ilgilidir. Bu inanışlar milletin kimliğini belirleyen önemli unsurlardandır. Günümüz Tatar halk inanışları animist ve totemist dönemler ile Şamanizm inancının etkilerini de içinde barındırmaktadır.

Halk bilimi ve halk edebiyatı ürünleri sözlü kültür ortamında oluşturulur ve aktarımı da yine sözlü iletişim ortamında yapılır. Bundan dolayı bu ürünlerin en temel kaynağı sözlü kaynaklardır (Artun, 2014:12). Orta Çağ'da bitki ve çiçekler hakkında her türlü bilgiyi derleyen araştırmacılardan Erasmus'a, Vicesimus Knox'a ve daha sonrakilere kadar tüm okuryazarlar, sözlü gelenekten kaynaklanan deyişleri kâğıda dökmüş; ancak bunların çoğu sözlü gelenekten değil yazılı kaynaklardan beslenmişlerdir. Değişen zaman ile birlikte ortaya çıkan Romantizm akımını 'romantik' yapan özelliği, geçmişe ve halk kültürüne duyulan ilgidir (Ong, 2003:29).

Modernizm anlayışı ile Batı dünyası Orta Çağ'da yaşadığı din/kilise eksenli hayata nokta koyup yeni bir başlangıç, bir yeniden doğuş hareketi başlatmış ve hayat tarzı, dünya algısı ile ilgili hemen her şeyini değiştirmiştir. Koçakoğlu (2012:16), âdeta zincirlerinden boşalan Avrupa, bütün kutsallarını ayakları altına alarak yeni mabedine sığınır, der ve bu mabedin bilim olduğunu ifade ederek Batı medeniyetinin doğuşuna giden bu yolun bilim endeksli olduğunu dile getirir.

Batı ve onunla neredeyse eş anlamlı olan modernizm, kilise ve Hıristiyanlıkla mücadele ederken kendine göre bilimsel olmayan her şeyi inkâr yoluna gitmiştir. Elbette zaman içinde bu anlayıştan hem diğer dinler hem de her türlü halk inançları etkilenmiştir. Diğer milletler ile mukayese edildiği zaman Tatarlar için durum, Sovyetler Birliği dönemindeki baskıcı ve asimilasyoncu anlayışın belirgin etkisi ile, iki kat daha ağır olmuştur. Ancak, bütün bu olumsuzluklara rağmen Tatar mitolojisi, Tatar halk inançları canlı şekilde günümüze kadar gelmeyi başarmıştır. Erman Artun'un (2013:93) ifadesi ile insanlar, en erken süreçlerden itibaren yaşamlarında tutunacak, güvenecek gizli bir varlık aramışlardır. Bu arayışlar ve inançlar, gökyüzündeki yııdızlar, ay, güneş, fırtına, gece, gündüz, ağaçlar, nehirler gibi bütün tabiat olgularından korkulan ya da çekinilen varlık ve olaylardan ilham almıştır.

Tatar halk edebiyatı içinde mühim bir yeri olan Tatar mitolojisi ile ilgili unsurlar değişik başlıklar altında incelenebilecek çok renkli, zengin ve çeşitli bir yapıya sahiptir. Bu yapı içinde iyelerin (koruyucu ruhların) farklı ve özel bir yeri vardır. Eski Türklerin Atalar Kültü'ne gösterdikleri saygı zaman içinde Koruyucu Ruh kavramını ortaya çıkarmışır (Candan, 2015:31). Koruyucu ruhlar yönünden çok zengin bir inanış sistemine sahip olan Tatarların günlük hayatlarında bugün de karşımıza Çeşme İyesi, Su Anası (Su Kızı), Su Atası, Su İyesi, Ev İyesi, Ahır İyesi, Munça (Hamam/Sauna) İyesi, Orman İyesi, Dağ İyesi, Biçura ve benzeri muhtelif iyeler (koruyucu ruhlar) çıkmaktadır. Her ne kadar modern hayatın bir neticesi olarak bu iyelere olan inanç bir miktar zayıflamış olsa bile günümüzde de Tatar halkı arasında bunların varlığına inanılmaya devam edilmektedir. Tatarların şair ve yazarlarının, bilhassa da Tatarların millî şairi Abdullah Tukay'ın, eserleri aracılığı ile bu inanışların yeni nesillere aktarılmaya devam edildiğini söylemek mümkündür. 
Her dil için olduğu gibi Tatarca için de bir zenginlik olan diyalektler, Tatarların manevî mirasının bir parçası, göstergesidir. Onlar; edebî dilin kökleri, dayanağı, direği olarak kabul edilmektedir. Tatar diyalektlerinde, mitolojik şahıs adları epeyce büyük bir tematik grup teşkil ederler. Tatarların kadim ataları mitolojik şahısların, çeşitli manevî varılıkların evde, evin müştemilatında ve bunların dışında tabiatta da yaşadıklarına inanmışlardır. Mitolojik şahısların adları da çoğu kez buna bağlı olacak biçimde doğmuştur (Bayazitova, 2011:84).

Tatar halk inanışında yer alan iyeler genel olarak olumlu, iyi varlıklar olarak kabul edilmektedir. Ancak bunların paralelleri olan olumsuz ruhların, ak iyelerin karşıtı olarak kara iyelerin, varlığı da söz konusudur. Ayrıca, insanların iyelerle ilgili olarak her zaman dikkatli olmaları, onlara hürmet etmeleri, onların haklarına saygı göstermeleri gerektiği gibi inanışlar da halk arasında yaygındır.

Kutsal ruhlar olan iyeler doğa ile yakın ilişki içindedirler. Tatarlar arasında, derin saygı duydukları bu iyelerle birlikte yaşadıklarına dair bir inanç vardır. Onların hakkına saygı göstermek, yaşadıkları mekânlara hürmet etmek, hak ettikleri şeyleri onlara vermek/adamak halk inanışına göre son derece önemli ve gereklidir. Zaten aksi bir durumda onların halk ile aralarının açlacağına ve halka karşı olumsuz davranışlar sergileyebileceklerine de inanılmaktadır.

\section{Su Altında Yaşayan İyeler}

\section{Tatar Mitolojisinde İyeler}

Her toplumun hayatında olduğu gibi Tatarların hayatında da mitlerin, efsanelerin, halk inanışlarının son derece mühim bir yeri vardır. Boratav (2014:120), efsaneler halkın çaresizliklerini, umutlarını, özlemlerini, dünya görüşlerini bütün öteki halk edebiyatı türlerinden daha keskin belirtirler; çünkü inanış konusudurlar büyük bir bölüğüyle, der ve onları saçma, akıl dışı diye küçümsemenin, zararıdır diye aforoz etmenin yersiz bir davranış olduğunu belirtir. Efsaneler gibi mitlerin de millet hayatında çok özel ve önemli bir yeri vardır. Erich Fromm (2014:189), tıpkı rüyalar gibi mitlerin de zaman ve mekân içerisinde gelişen bir tarihçeye sahip olduklarını belirtir. Ona göre mitler ya bilim öncesi ve saf dünya görüşünün sanatsal özelliğe sahip bir ürünü olarak görülebilir ya da mitlerin özünde gerçek bir olayın yattığı ve bunun sanatsal bir biçimde işlenmiş olduğu, böylelikle de zamanımıza kadar aktarıldığı düşünülebilir.

Tatar halk efsanelerinde ve rivayetlerinde Su İyeleri hakkında çok geniş ve zengin malûmatlar vardır. Genel olarak efsane ve rivayetlerde Su Dedesi, Su İyesi, Su Anası (Su Kızı), Su Atası adları geçmektedir. Galimcan Gıylmanov (1996:127), Su Dedesi'nin daha eski kaynaklarda da ele alındığını ve Su Anası'nın onun karısı; Su İyesi'nin ise onların oğlu olarak farz edildiğini belirtir. Fakat bu üç iye ile ilgili olarak günümüze ait efsane ve rivayetlerde fark olmadığını belirtmek gerekir, çünkü su ile ilgili iyeler sadece Su Anası adıyla geçmektedir.

Gennadiy Pospelov (2014:62), ilk insanların doğaya tümüyle bağımlı durumda bulunduklarını, doğa görüngülerinin gücünü, boyutlarını ve önemlerini kendi fantezilerinde yücelttiklerini, yani onları bilinçsizce tipikleştirdiklerini ifade eder. Böyle yüceltilmiş tasarımlar ve bunlara uyan imgeler, belli bir fantezi düzeyinin göstergesi idiler. Örneğin antropomorfizm (insanbiçimcilik, insandan 
başka şeyleri de insan biçimlerinde tasarlama), o zamanki düşünüşün tipik bir çizgisi idi. Tatar halk inanışlarındaki iyelerin de karakteristik özelliklerinden biri hepsinin insan suretinde olmalarıdır.

\section{Su Dedesi}

Suda yaşayan güçlü ve korkunç iyelerden biri olan Su Dedesi'nin çok intiyar bir dede şeklinde olduğuna inanılır (Urmançé, 2005:60). Tatar halkının inanışına göre bu iyeye ait olan yer "Su Padişahlığı" olarak adlandırılır. Göller, sulak alanlar ve bataklıklar ona ait yerler olarak kabul edilir. Su Dedesi'nin göl, bataklık veya nehirlerin kenarında yaşadığına; fakat hiçbir zaman kıyılara çıkmayıp insanlara görünmediğine inanılır. Aynı zamanda kendisini rahatsız edeni de sevmez ve bu yüzden de sulu yerlerin derinlerine girenleri, kendisini rahatsız ettikleri için cezalandırıp suyun dibine doğru çekermiş. Bundan dolayı suya batıp boğulan kişiler için eskiden, Su Dedesi almış, denilirmiş.

Halk inanışına göre, tabiatın bir parçası olan göllere, çeşmelere, nehirlere tüküren, genel olarak sulu yerleri kirleten, rencide eden kişilere Su Dedesi anında tepkisini gösterir. Böyle durumlarda güneşli güzel havalarda bile aniden göllerde, nehirlerde fırtına çıkar. Su Dedesi suyu dalgalandırıp havaya fırlatır ve bu şekilde su bentlerini, su değirmenlerini yerle bir eder. Bunlarla da bitmez Su Dedesi'nin kızgınlığı, insanların başına hastalık da açar. Halk dilinde Su Hastalığı olarak adlandırılan bu hastalık, insan vücudunda sulu kabarcıklar şeklinde ortaya çıkar. Eğer bir kişi böyle bir hastalığa yakalanırsa, bu kişi kim olursa olsun, onun suyu kirlettiği, rencide ettiği, yani Su Dedesi'ni kızdırdığı için böyle bir musibete uğradığı şeklinde yorumlanır içine düştüğü bu durum.

Galimcan Gıylmanov (1996:128), eski devirlerdeki insanların bu hastalıktan kurtulmak amacı ile yaptıkları bazı tedavi usulleri hakkında bilgi verip Su Dedesi tarafından böyle bir hastalığa maruz bırakılan kişilerin bu hastalıktan kurtulabilmek için bir avuç yarmayı tuzla karıştırarak çeşmeye, nehirlere veya göllere attıklarını, bazılarının ise bu yarmayı bir beze sarıp suya akıttıklarını ve bu esnada da "Nereden geldi isen oraya git, bu rahatsızlığı da alıp sahibine götür!" diye dualar ettiklerini belirtir.

\section{Su İyesi}

Sularla ilgili bir başka iye ise Su İyesi olarak adlandırılır. O, Su Dedesi'nden son derece farklı, genç ve tecrübesiz bir zattır. İnanışa göre, muhtemelen bu özelliklerinden dolayı, sık sık sulu yerlerde fırtınalar çıkartır. Güzel havalarda sebepsiz yere insanların suda boğulmasına sebep olur, hayvanları suyun dibine doğru çeker. Gıylmanov (1996:129), eskiden kalan bilgilere göre Su İyesi'nin değirmenlere de zarar verdiğine inanıldığını belirtir. Su İyesi'nin dikkat çeken bir yönü de huyunu anlamanın hiç mümkün olmamasıdır, yani onun ne yapacağı, bunu ne zaman ve nasıl yapacağı hiç belli olmaz. Kimi zaman güneşli ve rüzgârsız bir havada aniden bir fırtına çıkartır ve aynı hızla onu sonlandırır. Eskiler, Su İyesi'nin böyle huysuz bir varlık olmasını eşini kıskanmasına bağlarlar. Yani karısı olan Su İyesi'ni, Su Kızı kılığına girmiş olan Su Dedesi'nden kıskanır ve bundan dolayı kavga gürültü çıkarırmış. 
$\mathrm{Bu}$ bilgilerden hareketle Su İyesi'nin cinsiyetinin erkek olduğu anlaşılmaktadır; fakat o, efsanelerde uzun saçlı bir kadın olarak tarif edilmekte ve gece yarısı, insanların göl veya nehirlerin yanına gelemeyeceği bir vakitte, kıyıya çıkarak saçlarını taradığı anlatılmakta, buna inanılmaktadır. Kim olursa olsun, geceleyin sulu yerlere yaklaştığında öksürüyormuş gibi yapıp bir ses çıkartmalı, Su İyesi aniden korkmasın diye önceden onu uyarmalıdır.

Ural Tatarlarının inançlarına göre Su İyesi sarı saçlı, beyaz tenlidir. Halk inanışına göre biri suya batıp ölecek olursa Su İyesi korkunç sesler çıkararak bağıır; suya batan biri olduğu zaman da göl veya nehirlerin üstlerini dalgalandırarak bir uğultu çıkartır (Bayazitova, 2002:351). Bu inanış günümüzde de geçerlidir.

Su İyesi'ni Su Anası'ndan ayırma konusunda G.Gıylmanov (1996:130), ilgi çekici bir örnek verir ve görülen iyenin Su İyesi mi yoksa Su Anası mı olduğunu anlamak için onların kaşlarına bakılması gerektiğini belirtir. Buna göre; geniş, gür, güzel kaşlara sahipse Su Anası; kaşı yoksa Su İyesi'dir görülen iye.

Halk inancına göre Su İyeleri de insanlara hastalık verebilir. Bu hastalık, aynı Su Dedesi'nin verdiği hastalığa benzer bir hastalık olup vücutta beliren sulu kabarcıklar şeklinde görülür. Böyle bir hastalığa yakalanan insan tez zamanda Su İyesi'nden af dilemeli, duruma uygun bir ritüel yapmalıdır. Gıylmanov (1996:130), Tatar Mifları adlı çalışmasında bu ritüeli, "Böyle bir hastalığa yakalandığı zaman o insanın bir avuç tuz ve un karışımını alıp onu son defa suda yüzdüğü yere serpmesi gerekir. Hiç olmazsa tuz ve un karışımının vücudun sulu kabarcıklar çıkan yerlerine bez yardımıyla sarılması gerekir. Bunları yaparken de üç kere, 'Nereden geldi isen oraya git, sahibine götür!' denmesi şarttır." şeklinde ifade eder.

\section{Su Anası (Su Kızı)}

Su Anası veya kimi zaman adlandırılığı şekliyle Su Kızı, görünüş itibariyle bir insana benzer. Gıylmanov (1996:131), Su Anası'nın şeklinin büyük gövdeli, gür, siyah saçlarının yere kadar uzun; başının büyük ve uzun; gözlerinin kara, iri, pörtlek; teninin ise kırmızıya yakın olduğunu belirtir. Su Anası'nın göğüsleri geniş ve öne doğru çıkıktır. Kaşlarının ise olmadığına inanıı. Bundan dolayı Tatarlar arasında kaşı seyrek olan kişiler için "Su Anası" ifadesi kullanılmaktadır (Xäyrullin, 1999:22).

Su Anası da aynı Su İyesi gibi gecenin bir vaktinde saçlarını tarar. İnanışa göre insanlar onu da rahatsız etmemeli, korkutmamalıdır. Çünkü o, korkunç zatlardan sayılmaktadır. Bundan dolayı sulu yerlere yaklaşan kimse önceden seslenmeli, geldiğini ona belli etmelidir. Eğer Su Anası'nı uyarmadan sulu yerlere yaklaşııısa 0 , altın tarağııı bırakıp hemen suda kaybolur. Ama onun altın tarağını alan birisi olursa, tarağını geri almak için en kısa sürede gelip tarağını alan kişiyi bulur.

Su altında yaşayan Su Anası sadece saçlarını taramak için su kenarına çıkar ve oraya çıktığı zaman da karşılaştığı delikanlılar ve çocuklar ile irtibat kurarmış (Urmançé, 2005:60). 
Su Anası, çocukların kanı ile beslenir, yüzmeye gelen çocukların kanlarını emerek onları öldürürmüş. Ayrıca kendisine çocuk veren insanları sever; erkekleri ise yanına çağırıp onları ağırlamaktan hoşlanırmış (Xäyrullin, 1999:22).

Su Anası ile bazı Tatar Halk masallarında da karşılaşmaktayız. Bu iye, Tatar edebiyatında da geniş şekilde yer almıştır. Tatar halkının meşhur şairi Abdullah Tukay'ın (Özkan, 1994:446-447; Xisamov ve Möxämmätşin, 2006:134136), "Su Anası" adlı şiiri bu iye hakkında olup şiirde Su Anası'nın tarağını çalan delikanlıyı bulduğu anlatılmaktadır. Şair, şiirin sonunu iyi şekilde bitirir, yani tarağı çalan oğlanın annesi durumu anlayıp kapılarına gelen Su Anası'na tarağını vererek onun verebileceği cezadan ve zarardan oğlunu kurtarır. Çünkü Su AnaSı da diğer bazı iyeler gibi kendisine zarar verenleri cezalandırır. Hatta Galimcan Gıylmanov (1996:131), Su Tanrısı tarafından Su Anası'na insan kılığına girebilme, insanların fikir ve düşüncelerini duyup bilme yeteneği verilmiş olduğundan da bahseder.

Su Anası korkunç bir varlık olarak kabul edildiği için eskiden yaramazlık yapan çocukların onun adı ile korkutulduğu bilinmektedir. Su Anası'nın zararından korunmak için genç kızların, yeni gelin gelenlerin ve hamile kadınların sulu yerlere yaklaşmasına izin verilmez. Göl, nehir veya çeşme yanına gitmeleri gerekirse 0 insanın bu muhite geldiğini orada bulunan iyelere ifade etmek için seslenmesi gerektiğine inanılır. Ayrıca, akşama doğru çocukların suda yüzmemesi gerektiğine inanılır. İnanışa göre Su Anası, çocukları su altına çekermiş. Bununla da yetinmeyip hamile kadınların karnındaki bebekleri de çekip alırmış. Çocukların Su Anası tarafından alınması, suya batan çocuğun cesedinin nehir veya gölün öbür kıyısında bulunması veya battığı yer ile bağlantısı olmayan başka bir yerde bulunması gibi hususlar halk arasında yaygın şekilde anlatılır. Dahası, Su Anası insanlardan kendine kurbanlar da istermiş (Gıylmanov, 1996:131).

\section{Su Atası}

Tatarlar arasında yaygın olan halk inanışları ve anlatıları Su Atası'nın intiyar bir erkeğe benzediğini göstermektedir. Su Atası ile ilgili farklı bir durum söz konusudur. Diğer su iyelerinden farklı olarak onu çoğunlukla kışın görmek mümkündür. Gıylmanov (1996:132), Su Atası'nı, sakin bir zamanda nehir kenarına gelen insanların gördüğü, kışın balık avlamak için buz üstünde açılan delik yanında uzun sakalını ağaç tarakla tarayıp oturan ihtiyar, şeklinde tarif eder. Su Atası durduk yere insanlara zarar vermez, fakat kendisini rahatsız edenleri ve üzenleri hemen cezalandıır, kendisine doğru çekip alırmış. Bundan dolayı kışın nehir veya göl üstünde buzu tekmeleyip Su Atası'nın gazabına uğramaktan sakınmak gerektiğine inanııır.

Su Atası buz üstünde yapılan delikten yukarı çıktığında bu deliğe aniden buz kapatılır ve Su Atası'nın suya inme yolu kesilirse, buz üstünde öteye beriye yürümeye başlar. Şayet kış gecelerinde nehirlerin veya göllerin kenarına gelmeniz gerekirse oralarda "şırrr şırrr" gibi sesler duyarsınız. Kışın göl veya nehirde çamaşır durularsanız çamaşır, leğen veya kovanızı orada bırakmamalısınız, eğer bırakırsanız Su Atası onları etrafa saçacak, dağıtacaktır. Tatar halk inanışında önemli bir yeri olan Su Atası ile ilgili olarak Tatarlar arasında mitler, efsaneler, rivayetler az değildir. 
İ.Nadirov (1987:146), eski inançlara dayanarak, su altı iyelerinin insanlar ile irtibata girmekten kaçındıklarını, ancak değerli taşlar ve mercanlar ile süslü zengin padişahlıklarına sahip çıkarak huzur içinde yaşadıklarını belirtir.

\section{Yer Üstünde Yaşayan İyeler \\ Çeşme İyesi}

Çeşme İyesi de aslında su ile ilgili olan iyelerden biridir. Fakat onun diğer su iyelerinden farklı tarafı iyi ve kutsal olmasındadır. Çeşme İyesi her zaman insanlara yardıma hazır durumda ve şefkatli bir ana şeklinde tarif edilir. Gıylmanov, Tatar Mifları (1996:135) adlı eserinde Çeşme İyesi'ni, Muhabbet/Aşk/Sevgi İyesi olarak da adlandırır.

$\mathrm{Bu}$ iye halk dilinde değişik sıfatlarla anlatılır. Eskiden beri birbirini seven gençler genellikle çeşme civarında buluşur, sırlarını paylaşır ve en saf duygularını orada birbirlerine açarak söz verirlermiş. Bu gelenek Tatarlar arasında yirmi otuz yıl öncesine kadar canlı şekilde yaşamakta idi. Âşıkların verdikleri sözleri tutmamaları halinde eskiler, "Çeşme İyesi bunun böyle olmasını istemiştir.", diye söylerlerdi.

Günümüzde de, sık olmasa bile, eskiden kalan bu inançlarla karşılaşılmaktadır. Mesela Tataristan'ın başkenti Kazan'ın merkezindeki Kaban Gölü kıyısında birbirlerine söz veren, ancak evlenip müşterek bir hayat kuramayan âşıklar hakkında anlatılan efsaneler vardır.

İnanışa göre evlenip muratlarına eren çiftler her zaman Çeşme İyesi'ne teşekkür ederek her sene buraya gelip çeşmeyi temizler, çeşmenin oluğunu düzeltir, bazen dilekler dileyip suya iplikler atarak onları yüzdürür veya çeşmenin oluğuna renkli kurdeleler asarlar. Bu âdetler günümüzde de aynı şekilde devam etmektedir. Fakat evli çiftler değil, genellikle sevip de ayrılmış olan ve ikinci şansını arayan gençler dilek dileyerek suya iplikler bırakıp onları yüzdürür, aynı zamanda çeşme etrafında büyüyen ağaçlara renkli kurdeleler asarlar. Günümüzde yaşayan bu geleneğe göre suya bırakılan ipliğin renginin beyaz olması şarttır. Çünkü her inanç sahibi geleceğinin bembeyaz ve çeşme suyu gibi saf olmasını istemekte ve ipliğin rengi de sembolik anlamda bunu ifade etmektedir.

Günümüz yazarlarının roman veya öykülerinde çeşmeler hakkındaki bu geleneklerle ilgili anlatılara rastlanmakta; şairlerin şiirlerinde de çeşmelere çok önem verildiği görülmektedir. "Vücudun o kadar güzel, her tarafın gelişli/Hangi köyün sularından içtin sen?" gibi sözleri içeren Tatar halk türkülerinin varlığı da suya verilen önemi ve Tatarların hayatında ve Tatar romantizminde suyun yerini göstermektedir. "Väg'dä (Söz verme)" (Xäyrullin vd, 1999:89) adlı Tatar halk şarkısındaki, "Gün doğarken soğuk çeşme yanında/Karşılaştık biz sevgilimle bir daha." şeklindeki sözler de bunu göstermektedir. Eskiden birbirini seven genç kız ve delikanlılar burada birbirlerine söz verir, gençler gurbete veya askere gittiğinde de sevdikleri kızlarla çeşme başında son defa görüşür ve vedalaşırlarmış. Buradaki buluşmanın maksadı ne olursa olsun, her durumda bekleme ve bir gün kavuşma hususunda birbirlerine söz verirlermiş. Su ve çeşmelerle ilgili inançlar halk türküleri vasıtası ile Tatar edebiyatında da geniş bir şekilde yer almıştır. 
Çeşme İyesi'nin kadın şeklinde olduğuna inanılır. Hiç kimse tarafından görülmediği zamanlarda o, güzel bir kadın suretine girip su kenarında dinlenmeyi sever. İnsan suretine girmesi sonucu çevresine uyum sağıyor olması anlaşılabilir bir husustur, çünkü insan psikolojisi üzerinde yaşadığı yerin de etkisi vardır. İnsanların suyun civarına yaklaştığını hissettiği zaman, Ural-Batır Destanı gibi anlatılarda karşımıza çıkan 'don değiştirme' uygulamasının benzeri burada da vuku bulur, Çeşme İyesi bülbüle veya söğüt ağacına dönüşür. Bu gibi hususlardan dolayı halk arasında, su kenarında kuş avlamak veya ağaç kesmek hoş karşılanmaz; bunları yapan kişilerin elinin kuruyacağı, neslinin kesileceği, bir damla suya hasret kalarak öleceği şeklinde inançlar vardır (Gıylmanov, 1996:139).

Tatarlar arasında bazı çeşmeler kutsal olarak kabul edilmekte, bu çeşmelerden alınan suyun her türlü hastalığa iyi geldiğine, bir nevi şifa olduğuna inanılmaktadır. Bazen kutsal çeşmelerin suyu zemzem suyu ile de kıyaslanmaktadır. Mesela Tataristan'da hanlıklar devrinden kalan çeşmeler hakkında halk arasında bu tür inanışlar günümüzde de canlı şekilde yaşamakta, insanlar bu çeşmeleri günümüzde de ziyaret etmektedir. Dileklerinin kabul olunmasını isteyen kişilerce bu tür yerlere bozuk paralar atılmaktadır. Roma'daki aşk çeşmesi ile buradaki mütevazı çeşme arasında halk inancı yönünden hiçbir fark olmadığını, bu tür inançların insanlığın ortak değerlerinden biri olduğunu belirtmekte yarar vardır, diye düşünüyoruz.

Eskiden uzun süre yağmur yağmadığı zaman yağmur çağırma ayinleri -bir çeşit yağmur duası- de çeşmelerin yanında yapılmışıı. Bununla ilgili olarak Gıylmanov (1996:138-139), önce büyükler saflar oluşturarak çeşme etrafına otururlar, dua ederler ve çömelip sıra ile çeşmenin suyundan içerler, suyu yüzlerine ve göğüslerine sürerler, der. İnanışa göre, böyle yapıldığı zaman Çeşme İyesi kişilerin dileklerini Göğe/Tanrı'ya iletir, yer için ve insanlar için yağmur talep edermiş. Bu ritüel uygulandıktan sonra yağmur yağarsa insanlar yine çeşme yanına gelip ona, Çeşme İyesi'ne, teşekkür edip Tanrı'ya da dua ederlermiş.

Kazan-Tatar Türkçesinde çeşme ile eş anlamlı bir kelime daha vardır: кизләү (kizläw). Bu kelimeyi Türkiye Türkçesindeki "göze" kelimesi gibi düşünmek mümkündür. "Evliya kizläwläri (Evliya çeşmeleri)", Tataristan'ın hemen hemen her şehrinde ve her köyünde vardır. Halk tarafından kutsiyet atfedilen bu çeşmelerin yanında insanlar kurban keserler. Gıylmanov'un (1996:137) belirttiğine göre bir defa kutsal kişilerin çeşmesine gelip hayır dağıtan, kurban kesen ve ibadet eden kişi bunu devamlı yapmalıdır, aksi halde bu insanın hayatı alt üst olabilir, hatta bu kişi için ölüm tehlikesi bile söz konusu olabilir.

Çeşme İyesi, Tanrı kızıdır ve dağın kucağında yaşar. Bu kutsal ruh yer altı, yer üstü ve gök dünyasını birleştiren ilahî bir köprü vazifesini gören ruh olarak kabul edilmelidir.

Çeşme suyunun halk inançları yönünden önemli bir özelliği daha vardır. Bu su ile fal da açılabilir. Çeşme suyu ile fal açma uygulamalarına doksanlı yıllara kadar rastlanmaktaydı. Bunun için sabahleyin daha çeşme başına kimse gitmeden su getirilir ve temiz bir bardağa konulup içine bir altın yüzük atılırdı. 
Bu suda fal baktıran kişinin müstakbel eşinin yüzünü görebileceği inancı yatmaktadır.

\section{Dağ İyesi}

Tatarlarda çeşmeler ile ilgili birçok efsane, rivayet ve mitlere rastlanır. Çeşmelerin su kaynağı dağ olduğu için, tüm çeşmelerin atası olarak Dağ İyesi kabul edilir. GıyInamov (1996:138-140), bu mitleri bir araya topladığımız zaman suyun başı çeşme, bu çeşmenin atası Dağ İyesi, anası dağ koynundaki su, çocuğu nehir, torunları deniz ve deryadır, şeklinde bir mitin ortaya çıtığını belirtir.

Dağ İyesi, "Korık" diye de adlandırıır. Eski Türkçede "korık" kelimesi "dağ ağzı" anlamına gelmekte idi. Ayrıca Sümerlerin "kur" kelimesini "dağ", "dağ ili" anlamında kullandıklarından ve Dağ İlinin İyesi'ni bu kelime ile karşıladıklarından söz edilir. Gıylmanov (1996:116-117), Etrüsklerdeki "haru" sözünün Türkçe "korık" sözüne yakın oluşuna da vurgu yapar; eski Türk ve Fin-Ugor kabilelerinin dillerinde "korık" sözünün "Yer İyesi" veya "Dağ İyesi"ni anlattığını belirtir.

Günümüzde halk arasında Dağ İyesi ile ilgili inançların yok denilebilecek kadar az olduğunu söylemek mümkündür. Ancak pek eski rivayetler yardımı ile Dağ İyesi hakkında bilgi edinilebilir. Türk mitolojisinde Dağ İyesi hakkındaki mitlerin azlığının, bu iyenin adının ve varlığının zayıflamasının sebebi olarak Fars mitolojisinden geçen devlerin onun yerini almış olması gösterilebilir. Devler, yer altı dünyasının olduğu gibi dağların da sahibi olarak kabul edilirler (Gıylmanov, 1996:118). Hint-İran kökenli "dev" sözcüğü, Türk aktarımlarında da, Fransız masallarının insan yiyen devi Ogre ve yine Fransız aktarımlarındaki Gigant'a karşılık gelen iki farklı doğaüstü yaratığa eş değer kullanılan bir terimdir (Boratav, 2012:62).

\section{Ev İyesi}

Ev İyesi (Tatarlar arasında Ev Annesi, Ev Babası, Dede, Yurt Ninesi, Yurt Dedesi gibi birçok adı vardır) hakkında da Tatarlar arasında pek çok mit bulunmaktadır. Kişiler onlarla devamlı 'karşılaşmakta' ve bundan dolayı da bu iyeler bu kişilerin hayatlarının merkezinde kendilerine ait bir yer bulmaktadır. Bu iyeler ile ilgili inanışlar günümüzde de halk arasında yaygın ve canlıdır. Yediden yetmişe her Tatar, Ev İyesi hakkında bir şeyler mutlaka bilir, lakin bu biliş her ferdin kendine göredir. Herkese farklı şekillerde görünmesine rağmen Ev İyesi'nin herkes için ortak özellikleri de vardır. O, yaşı̆ı birini hatırlatan, uzun beyaz saçlı, insan boyundan küçük bir boya sahip bir varlık olarak tasvir edilir. Ayrıca, genellikle beyaz bir giysi ile gezen Ev İyesi'nin beli de biraz kamburdur. Ev İyesi, Kreşinler (Hristiyan Tatarlar) tarafından "Kırsut" olarak adlandırılmaktadır (Bayazitova, 1995:132).

Ev İyesi'nin yerin altında/evin bodrum katında yaşadığına inanılır. Ev İyesi gün içinde yerinden çıkmaz. Halk arasındaki inanca göre Ev İyesi sadece ev sahipleri uykuya daldıktan sonra ortaya çıkar ve insanlara yardım için bir şeyler yapar. Mesela yün eğirir, sobaya odun doldurur, küçük çocuk ağlarsa onu sakinleştirir vb. gibi. Ayrıca, eve kaza bela gelecek olursa bir şekilde ev sakinlerini bundan haberdar eder. Gece yarısı ev sahiplerinin başına istenmeyen 
bir şey gelecek olursa, bir belaya maruz kalacak olurlarsa, evdekilerden birini ayağından çekip uyandırır. Bazen de ev sahiplerini uyandırıp onları bu menfi durumdan haberdar etmek için değişik sesler çıkarır. Çocuk doğurma özelliğine de sahip olduğu kabul edilen Ev İyesi ile ilgili olarak Tatarların yaşadıkları bazı bölgelerdeki inanışlara göre ev sahibi erkek vefat ettikten sonra Ev İyesi'nin de öldüğüne inanılır (Bayazitova, 1995:131).

Ev İyesi ile ilgili halk inanışı günümüzde de halk arasında yaşamaya devam etmektedir. Bazı kimseler geceleri sanki evde biri yürüyormuş gibi bir hisse kapıldıklarını belirtmekte ve bunun Ev İyesi olduğuna inanmaktadırlar. Kimileri ise giysilerinin veya çamaşırlarının bıraktıkları yerde olmadığını, aradıkları zaman eşyalarını bıraktıkları yerde değil de evin başka bir köşesinde bulduklarını belirtmekte ve bu durumu Ev İyesi ile ilişkilendirmektedirler.

Ev İyesi'nin insanlara yardım etmesi yanında onun kişilere görünüş şekilleri de farklı farklı yorumlanmaktadır. Bilhassa yaşlılar arasındaki inanca göre Ev İyesi'ni un elerken gören insanların maddî durumu iyileşir. Eğer Ev İyesi'ne pabuç yaparken rastlanırsa, bu, ev sahiplerinin yoksullaşacağı şeklinde yorumlanır. Bu husus ile ilgili bir başka inanca göre Ev İyesi evdekilerden kimi severse sadece ona görünür.

Ural Tatarlarında, Ev İyesi için kurban kesilmesi gerektiği inancı vardır. Halk inanışına göre Ev İyesi'nin kendisi insanlara görünerek kurban talebinde bulunur. Yine inanışa göre, eğer kurban kesilmezse ev sahiplerinin başına bir bela gelir, huzurları kaçar, evde kavga olur, türlü türlü rahatsı edici sesler duyulmaya başlanır. İnanışa göre, kurbanlık olarak seçilecek hayvanın yünlü bir hayvan olması gerekir. Bu sebeple Ev İyesi için genellikle koyun kurban edilir (Bayazitova, 2002:355).

Eski devirlerde, Ev İyesi'ne iyi davranmak gerektiği ile ilgili husus küçük yaştan itibaren çocuklara anlatılırmış. Bu geleneğin günümüz Tatar ailelerinde de kısmen devam et(tiril)mekte olduğunu söylemek mümkündür. Mesela eve girmeden önce Ev İyesi'ne selam verme âdeti hâlâ vardır. Yeni eve taşınan bazı kişilerce Ev İyesi de yeni eve götürülür. Bunun için bir çift terlik alınıp akşamdan eski evde bırakılır ve ertesi gün, "Ev İyesi, terliklerini giy, yeni evimize gidiyoruz!" diye ona seslenilir ve evde bırakılan terlikler alınıp yeni eve götürülür. Bazı yerlerde ev sahipleri yeni eve taşındıklarında Ev İyesi büyük bir fırçaya, bazı yerlerde ise oklavaya veya elbisenin eteğine oturtularak yeni eve götürülür (Bayazitova, 1996: 122-125, 133).

Tatar halk inanışlarına göre ev sahipleri Ev İyesi ile iyi geçinmeli, onunla münasebetlerini iyi tutmalı ve ona iyi davranmalıdır. Aksi halde, halk inanışına göre, Ev İyesi'nin öfkelenerek onlara kötülük yapma ihtimali söz konusu olabilir.

\section{Ahır İyesi}

Her toplumda olduğu gibi Tatarlar için de evcil hayvanların çok büyük bir önemi ve değeri vardır. Evcil hayvanların Tatar halkının hayatındaki önemli rolleri dolayısı ile halk inanışlarında bu hayvanların yaşadığı yerlerle, yani ahırlarla, ilgili olarak da iyeler var edilmiştir, denilebilir diye düşünüyoruz.

Ahır İyesi, hayvanların yaşadığı ahırda bulunan iyedir. Onun görevi, bulunduğu ahırdaki hayvanları korumaktır. Ahır İyesi'nin ahırda çok sevdiği bir 
hayvanının olduğuna inanılır. Bununla ilgili olarak halk arasında memorat tarzı pek çok anlatı mevcuttur.

Ahır İyesi'nin insanlara değişik şekillerde fayda getirdiğine inanılır. Halk inancına göre, ahırdaki hayvanlardan biri yavruladığı zaman Ahır İyesi bu hayvana yardım eder ve bu haberi bir şekilde ev sahibine iletir. Günümüzde de sığırı, koyunu veya atı yavruladığı zamanlarda insanların, "Atın/sığırın/koyunun yavruluyor!" gibi sesler duydukları; böyle bir doğum hadisesi gece yarısına denk gelirse Ahır İyesi'nin gelip ev sahibinin penceresini tıklayıp onu uyandırarak bu durumdan haberdar ettiği şeklinde bir inanç vardır. Gıylmanov (1996:217), Ahır İyesi hakkında dikkat çekici bir hususa değinir. Tatarların yaşadığı bazı yerlerdeki ilginç inançlara göre Ahır İyesi keçi ile köpeğe dokunmaz, onları rahatsız etmez. Gıylmanov'a göre bu inanç Slavyan halkların mitolojisindeki inançlarla benzerdir.

Ahır İyesi'nin insan şeklinde olduğuna inanılır, ancak o bazen insanlara bir hayvan olarak da görünebilir. Fakat her iki durumda da onu sadece geceleri ve uzaktan görmek mümkündür.

Farklı bölgelerde yaşayan Tatarlar arasında Ahır İyesi ile ilgili farklı adlandırmalar söz konusudur. Sibir Tatarları'ndaki Mal İyesi veya Cenki (Zenki) Baba, Ahır İyesi'ne yakın olan iyelerdendir (Urmançé, 2005:60). Ural Tatarlarında da Ahır İyesi, Zenki Baba olarak adlandırılmaktadır. Halk arasında onun hayvanları ve ahırları koruduğuna inanıır. Onun ruhu için ayetler okunması ve hayvanlar sağ olsun diye sadaka verilmesi gerektiğine de inanılır (Bayazitova, 2002:353-354).

Tatar halk inanışına göre Ahır İyesi'ni öfkelendirmekten uzak durulmalıdır. Eğer o kızdırılırsa ev sahibine hastalık bulaşır veya ev sahibinin hayvanları ölür. Bu iye ile ev sahiplerinin arası iyi olmalıdır. Ev sahipleri, Ahır İyesi'nin rızasını alabilmek için sadaka verip dua ederler.

\section{Munça (Hamam/Sauna) İyesi}

Bu iyenin küçük boylu ihtiyar bir varlık şeklinde olduğuna inanılır. Ancak, insanlar bu iyeyi cinler ve perilerle karıştırıyorlar. Bu iye de kendini rahatsız etmediği sürece insanlara zarar vermez ve bu yönü ile cinlerden, perilerden ayrılır. Halk inancına göre ikindi ile akşam arasında insanlar munçaya girmemelidir. Güneş batmak üzere iken, yani ikindi ile akşam vakti arasında, Munça İyesi'nin kendisi yıkanır ve bu vakitte rahatsız edilmemesi gerekir. Ayrıca, normal vakitlerde de insanlar munçaya girerlerken hafifçe öksürerek oraya girdiklerini Munça İyesi'ne haber vermelidirler.

Günümüzde Tatarlar arasında hamamlardaki leğenlerde kalan temiz suyu kullanmanın yasak olduğu şeklinde bir inanç vardır. Bunun görünen iki sebebi vardır. İlki, kalan su ile Munça İyesi yıkanabilir; ikincisi ise, bu suya cinlerin veya perilerin tükürmüş olabileceği düşüncesidir. Munçaya giren insanlar genellikle bu suyu döker, bazen ise besmele çekerek veya bu suya dualar okuyarak yıkanırlar. Yine de insanlar hamamdaki leğende veya kovada açık şekilde su bırakmamaya özen gösterirler.

Gıylmanov'a (1996:224) göre munçada yıkanılırken Munça İyesi insanları rahatsız etmez. Yine de burada bu iyelerin varlığını anlamak mümkündür. Onlar sanki yanımızda su dökünüp yıkanıyorlarmış gibi sesler çıkartır veya soba ile 
duvar arasındaki boşluktan küçük küçük taşlar atar, lifi çeker, bazen de tam yüz sabunlandığı anda su kovasının yerini değiştirir veya leğendeki suyun tamamını yere dökerler. Halk inanışına göre Munça İyesi'nin varlığını kanıtlayan bir başka husus da bu iyelerin munçadaki leğene vurarak ses çıkartmalarıdır.

Günümüzde Tatarlar arasında varlığını devam ettirmekte olan bir halk inanışına göre genç kızların ve kadınların yalnız başlarına munçaya girmeleri doğru kabul edilmez. Ayrıca, munçada yıkanmanın geç saatlere bırakılması da doğru sayılmaz.

Munça İyeleri ile ilgili olarak halk arasında yaşayan bir inanca göre onlar da kendi aralarında evlenip aile kurmakta ve çocuk sahibi olmaktadırlar.

\section{Orman İyesi}

Tatarlardaki Orman İyesi, eski mitlerdeki Orman Tanrısı'na benzer bir iyedir. Tatar halkının muhayyilesindeki Orman İyesi genellikle yaşlı bir adam şeklinde tasvir edilir. Onun görevi ormanları, ormandaki tüm canlıları korumak olarak tarif edilir. İnsanlara hiçbir zararı olmayan Orman İyesi'nin onlara yardım etmeyi seven bir iye olduğuna inanilır. Mesela ormanda yolunu kaybedenlere yol gösterir, fakat kendi mülkü olan ormanlara zarar verenleri ise hemen cezalandırır.

Orman İyesi ile genellikle Tatar halk masallarında karşılaşılır. Yazarların ve şairlerin eserlerinde Orman İyeleri ile ilgili hususların kaleme alındığı görülür. Tatar halkı tarafından ormanda yaşayan varlıklar arasında Şüräli (bir çeşit dev) adı ile bilinen bir varlık olduğuna da inanılmaktadır. Şüräli, meşhur Tatar şairi Abdullah Tukay tarafından kaleme alınan bir peomanın da konusu olmuş ve halk arasında, bilhassa çocuklar ve dolayısı ile yeni nesiller arasında, daha da yaygınlaşmıştır. Abdullah Tukay (Xisamov ve Möxämmätşin, 2006:39-40; Özkan, 1994:281), Şüräli'yi şöyle tasvir etmiştir:

"Korkunç, çirkin, acaba nasıl bir varlıktır bu!

Burnu eğri büğrü, kıvrımlıdır, tıpkı tırmık gibi;

Çarpık çurpuktur elleri, ayakları dal budak gibi.

Işsl ışıl ışıldar, çukura kaçmış gözleri,

Ödün patlar, değil gece, görsen gündüzleri.

Çırılcıplak, incecik, ancak insana benzer kendisi;

Alnında vardır, orta parmak uzunluğunda boynuzu.

Eğri değildir parmakları, dümdüzdür,

Çirkin parmakları, yarım arşından uzundur."

Şüräli, ormana gelen insanları rahat bırakmaz; onları gıdıklamayı sever ve böylece, yani gıdıklayarak, kurbanlarını öldürür.

Tatarların mitolojik inançları ile ilgili bir araştırmasında Çulpan ZaripovaÇetin (2007:9), Şüräli hakkında ilgi çekici malûmatlar verir ve onun koltuk altlarında delikler olduğunu, bu deliklerden onun bütün iç organlarının gözüktüğünü belirtir. Şüräli, koltuk altlarında yer alan deliklere ağaç budağı saplanması halinde öleceği korkusu sebebiyle hiçbir zaman kollarını havaya kaldırmazmış.

Şüräli, vücut yapısı itibarı ile insana benzer, fakat insanlardan farklı olarak onun vücudunun tamamı kıllarla kaplıdır. Halk inançlarında Şüräli, türlü sesler 
çıkararak insanları aldatıp kendine çeken, at binmeyi seven, biraz ahmak görünüşlü, alnında boynuzu olan, parmakları uzun bir varlık olarak tasvir edilir. Şüräliler hem erkek hem de dişi olurlar ve ormanda ailece veya sürüler halinde yaşarlar. Dişi Şürälilerin memelerinin çuval kadar olduğuna inanılır. Öyle ki ana Şüräliler memelerini omuzlarından arkaya doğru atarak gezerler (Şämsi, 1997:244-245). Udmurtiya ve Kirov Tatarları arasındaki inançlara göre Şüräli'nin kendisi uzun boylu, memeleri de büyük ve uzun olur. Memelerini omuzlarından arkaya doğru atarak yürüyen bu varlıklar Udmurtiya ve Kirov Tatarları tarafından Orman Anası olarak adlandıııı. Orman Anası'nın yılanları emzirerek beslediğine de inanilır (Bayazitova, 2006:159).

Şüräliler biraz eğilerek yürür ve insan gibi konuşurlar. Onların insan dilini kullanması insanları harap eder. Öyle ki Şüräliler ormanda kendileri için yardım, imdat talep eden bir ses çıkartarak insanları yollarından alıkoyup ormanın en karanlık köşelerine çeker ve -daha önce de belirtildiği gibi- gıdıklayarak öldürürlermiş.

Fatix Urmançé (2005:59), Şüräli'nin birçok yönden Orman İyesi ile benzer tarafları olduğunu, ona benzediğini belirtir ve onun da bir "Orman İyesi" olarak adlandırılması gerektiğini ifade eder.

Görüldüğü gibi Şüräli son derece eğlenceli ve hoş bir Orman İyesi olarak ön plana çıkmaktadır. Tatarların millî şairi Abdullah Tukay (Gabdulla Tukay, 1886-1913)'ın Şüräli ile ilgili poeması halkın muhayyilesini derinden etkilemiştir. Ayrıca, Tukay'ın Şüräli tasviri Tatar sanat âlemine de derinlemesine etki etmiş; resim, heykel, bale gibi alanlarda onun tasvirlerinden doğan Şüräli tipleri ortaya çıkmaya başlamıştır. Halk inancı ve geleneğin Tukay'ın şiirleri vasıtası ile sanatla birleşmesi Şüräli/ler ile ilgili inancı yeni nesillere taşımış ve kültür aktarımı konusunda bir nevi köprü olmuştur.

Tatar masallarında ayrıca insanlara kötülük eden "Ubır/Ubırlı Karçık" ve "Calmavız" da yer alır. Ubırlı Karçık, Kara Orman'da yaşar ve orada karşılaştığı kişilere kötülük eder (Gültekin, 2013: 366-367).

\section{Cami İyesi}

Cami İyesi ile ilgili olarak halk arasında çeşitli anlatılar vardır. Bu muhayyel varlık halk arasında Cami İyesi veya Cami Cini diye adlandırılır. Yukarıda anlatılan diğer bazı iyeler gibi bu iyenin de insanlara zararının dokunmadığına inanııır. Bu iye ile karşılaşan insanlar onun beyaz elbiseli bir intiyar olduğundan bahsederler. Cami İyesi de kişilere yardım etmeyi sever, bazen ise insanların terliklerini saklayarak veya seccadelerini çekerek onlarla şakalaşır.

Halk arasında anlatılagelen bilgilere göre, yirminci yüzyılın otuzlu yılarında Bolşeviklerin kararı ile Tatar köylerinde camilerin minareleri yıkııı. Minaresi yıkımış olan camilerin içinde bazen ağlayan insan seslerini, bazen de birilerinin koşuşma seslerini duyanlar olurmuş. Ayrıca, cami eşyalarının öteye beriye dağıtılması gibi durumlarla da karşılaşılırmış. Minaresi yıkılmış olan camiler daha sonra okula, anaokuluna, çoğunlukla da kültür merkezlerine dönüştürülmüş ve ibadethane olma işlevlerine son verilmiştir. O vakitler soba ile ısıtılan birer okula dönüştürülen camilerde çalışan kişilerin şahit olduklarını iddia ettikleri kesilecek odunların hazır olduğu, sobanın doldurulmuş veya yakılmış olduğu, camilerden 
dönüştürülen bu okullarda çalışan kişilerin geceleri çocukların seslerini duydukları gibi memorat tarzı anlatılar vardır.

Kültür merkezine dönüştürülmüş olan camilerde de bazen okula dönüştürülen camilerdekilere benzer olaylar olurmuş. Halk arasında dolaşan anlatılara göre camiden kültür merkezine dönüştürülen bu yerlerde duyulan ağlama sesleri hiç kesilmeden devam edip gidermiş. Bu anlatılarda, camilerin bir kültür/eğlence merkezine dönüştürülmesine duyulan tepkinin dile getirildiğini görmek mümkündür.

Halk inanışına göre diğer iyeler gibi Cami İyesi de kendi huzurunu bozanları cezalandırarak onlara hastalıklar verir, ayrıca beddua da edermiş.

\section{Sonuç}

Dinlerin doğuşundan önceki dönemlerde veya ilkel dinlerin var olduğu devirlerde oluşturulan inançlar ve bu inançlarla ilgili kavram ve varlıklar, diğer milletlerde olduğu gibi Tatarlar arasında da İslam dini kabul edildikten sonraki dönemde de yaşamaya devam etmiş, halen de varlığını devam ettirmektedir. Ancak, hem İslam dininin hem de modern hayatın etkisi sonucu bu kavram ve inançların halk nezdindeki inanılırlık dereceleri zayıflamış, bazıları ise bütünüyle unutulup gitmiştir.

Tatar halkının İslamiyet öncesi hayatları ile ilgili olan halk inançlarının İslam dini kabul edildikten sonra kllık değiştirip İslamî bir şekle bürünerek varlıklarını devam ettirmeleri dikkat çekici bir husustur. Burada, İslamiyet'i kabul eden Tatar halkının eski inançlarından kopmayıp onları da kendileri ile birlikte bu yeni dine taşıyarak Müslümanlaştırdıklarını görülmektedir. Buna benzer pek çok farklı hususun Müslüman Tatarlar ve diğer Türk soylu halklar arasında var olduğu da bilinmektedir.

Tatar halk inançları arasında yer alan önemli unsurlardan biri olan iyeler ile ilgili inançların günümüzde de Tatar halkı arasında canlı bir şekilde varlığını devam ettirdiği görülmektedir. İyelerin, Su Anası hariç, kendilerine zarar verilmediği takdirde onların da insanlara hiçbir şekilde dokunmadığı, zarar vermediği şeklinde büyük çoğunluğunda ortak olan bir paydanın varlığı görülmüştür. Çünkü bu iyeler koruyucu olma özelliğine sahiptir; yani hepsinin ortak özelliği, kendilerine ait mülke zarar gelmesine mani olmak ve bu şekilde sorumluluk alanlarını muhafaza ederek doğadaki düzenin dengesinin devamını sağlamaktır.

Çalışmada görüldüğü üzere bu iyeler her zaman olmasa da çoğu zaman insanlara yardımcı olan varlıklardır. Aynı zamanda onların yaptıkları bu iyilikler için bir karşlık bekledikleri ve bunu istedikleri de görülmektedir. Lakin bu karşılığın onlardan daha çok insanların faydasına olan şeyleri içerdiği de görülmektedir. Daha önce belirtildiği gibi, iyelerin talep ettikleri karşlık doğadaki mutat dengenin bozulmaması ile ilgili olup her daim insanların faydasınadır. İyi huylu iyelerin öfkelendikleri zaman insanları cezalandırmaları, onlara hastalıklar vermeleri kendi durumları ile bir tezat teşkil ediyormuş gibi görünse de bu durum onların tabiattaki ve umum insanlık âlemindeki dengeyi koruma çabaları ve gayeleri ile ilgilidir. 


\section{Kaynakça}

ABDULLİN, İ.A., G.X.Axuncanov, S.B.Vaxitova vd. (1979). Tatar Télénén Aplatmalı Süzlégé. Kazan: Tatarstan Kitap Näşriyatı.

ARTUN, Erman (2013). Türk Halkbilimi. Adana: Karahan Kitabevi. Kitabevi.

ARTUN, Erman (2014). Türk Halk Edebiyatına Giriş. Adana: Karahan

ÄXMÄTOVA-URMANÇÉ, Flora, Rafis Korban (2006). Gabdulla Tukay Şürälé. Kazan: Tatarstan Kitap Näşriyatı.

BAKİROV, Marsel' (2014). Drevnetürkskaya Poeziya. Kazan: Tatarskoe Knijnoe İzdatel'stvo.

BAYAZITOVA, F.S. (2011). "Abdullah Tukay'ın Eserlerinde Ve Mahalli Ağızlarda Mitolojik Şahıslar ('Su Anası' İzinden)". (Aktaran: Seher MEMiş). Türk Dünyası Dil ve Edebiyat Dergisi, S.32, s.83-90.

BAYAZITOVA, Flera (2006). Nokrat Söyläşé. Ruxi Miras: Gailä-könküréş Häm Yola Terminologiyäsé. Kazan: "Dom Peçati" Näşriyatı.

BAYAZITOVA, Flera (2002). Urta Ural (Sverdlovsk Ölkäsé) Tatarları. Kazan: Fikér.

BAYAZITOVA, F. (1995). Tatar Xalkının Bäyräm Häm Könküréş Yolaları. Kazan: Tatarstan Kitap Näşriyatı.

BORATAV, Pertev Naili (2014). 100 Soruda Türk Halk Edebiyatı. Ankara: BilgeSu Yayıncilık.

BORATAV, Pertev Naili (2012). Türk Mitolojisi (Oğuzların-Anadolu, Azerbaycan ve Türkmenistan Türklerinin Mitolojisi). Ankara: BilgeSu Yayıncılık. Yayınları.

CANDAN, Ergun (2015). Türklerin Kültür Kökenleri. İstanbul: Sınır Ötesi

ÇETİN-ZARİPOVA, Çulpan (2007). "Tatar Türklerinde Mitolojik Varlıklarla İlgili Mitler Ve İnanışlar (İyeler ve Yaratıklar)." Bilig Dergisi, S.43, s.1-32.

ÇOBANOĞLU, Özkul (2005). Halkbilimi Kuramları ve Araştırma Yöntemleri Tarihine Giriş. Ankara: Akçağ Yayınları.

DÄWLÄTŞİN, Gamircan (2009). Borın-Borın Zamanda... Mif Din Sängat'. Kazan: Tatarstan Kitap Näşriyatı.

FÄXRÉTDİNOV, R.G. (1996). Tatar Xalkı Häm Tatarstan Tariyxı. Kazan: "Mägarif Näşriyatı". 
FROMM, Erich (2014). Rüyalar, Masallar, Mitler (Çev. A.Arıtan, K.H.Ökten). İstanbul: Say Yayınları. Näşriyatı.

GIYLMANOV, Galimcan (1996). Tatar Mifları I. Kazan: Tatarstan Kitap

GÜLTEKİN, Mustafa (2013). Kazan Tatar Masalları (İnceleme-Metinler). Ankara: AKM Yayınları.

KOÇAKOĞLU, Bedia (2012). Anlamsızlı̆ın Anlamı Postmodernizm. Ankara: Hece Yayınları.

NADİROV, İ. (1987). "Süz Sängaténén Başı - Xalık İcatında." Şu kitapta: Haz. Ymär Daher. Tatarica. Vammala: Vammalan Kirjapaino Oy, s.145-157.

ÖZKAN, Fatma (1994). Abdullah Tukay'ın Şiirleri (İnceleme-MetinAktarma). Ankara: Türk Kültürünü Araştırma Enstitüsü Yayınları.

POSPELOV, Gennadiy (2014). Edebiyat Bilimi (Çev. Yılmaz Onay). İstanbul: Evrensel Basım Yayın.

SEYİDOĞLU, Bilge (1999). Mitoloji. Kayseri: Bizim Gençlik Yayınları.

URMANÇÉ, Fatix (2002). Tatar Xalık İcatı. Kazan: Mägarif Näşriyatı.

XÄYRULLİN, İ.K., R.M.Minnullin, R.S.Möxämmädiyev， X.Ş.Mäxmutov， M.X.Väliyév (1999). Süz İçéndä Xikmät Bar. Kazan: Mägarif Näşriyatı.

XİSAMOV, Nurmöxämmät, Zöfär Möxämmätşin (2006). Gabdulla Tukay (Saylanma Eserler) I Tom. Kazan: Tatarstan Kitap Näşriyatı.

ŞÄMSİ, Soltan (1997). Yıllar İzé: Xikäyälär, Piyesa, Publitsistika. Kazan: Tatarstan Kitap Näşriyatı. 